\title{
Instrument Development for Studying Work Life Balance Programs in Information Technology Firms
}

\author{
Kumar Viswanathan, Dr. Jeyakumaran, \\ Department of Business Administration, Kalasalingam University, India \\ Head of the Department, Kalasalingam University.
}

\begin{abstract}
The purpose was to construct a comprehensive instrument to study the impact of moderating variables on the independent variables with respect to work life balance in IT companies in India. The Design/Methodology/Approach included questions that were made for the specific social culture based on the objective of the study. Experts' opinion was gathered and an iterative process ensured that the instrument was corrected. Content validity test, pilot study and reliability test were performed to finalize the instrument before the data collection exercise started. The instrument created through the above-mentioned process ensured easy data classification and relevance to the research. Various hypotheses were tested and a detailed analysis was possible due to the way the questions and options were offered to the respondents. This instrument was administered to IT employees in India, which has a unique social fabric due to its diversity and cultural differences.
\end{abstract}

\section{Introduction}

Work life balance is often an intriguing phenomenon with wide range of thoughts and responses. It is culture and context sensitive and can potentially throw varied results. There are two schools of thoughts on this subject at a very high level. One advocates that it is work that invades family and the other one counters it by stating that it is the other way around. Both can be true or false and it is primarily driven by which side of the fence one is more attached to. It can also change over a period of time for the same person as he/she evolves as worker as well as a family person when he/she goes through different stages in life. At times, employees do develop a negative attitude towards work due to imbalance created in his/her world.

It becomes complex as the roles and responsibilities of an individual is unclear in family compared to work. This also gives rise to conflict and thus the issue becomes much bigger that has an impact both at family as well as at work.

It is believed that work life balance is about people's ability to exercise control and have a tight grip of what happens at work as well as at family, without compromising on the deliverables in both the roles at all times. Further, when the individual is able to fulfil the needs of society and friends, apart from playing the role at family and at work that is when the balance is achieved in total.

The time spent for work has evolved and has been constantly changing over the last two decades in India. Some people carry work home spending late nights to complete assignments. The technological blessings like email, text messaging and cell phones which were thought of as tools to connect them to their work being away from their workplace, have actually integrated their personal and professional lives. Now professionals find themselves working even when they are on vacations. In a country like India completing errands like ration card, voter identification card, obtaining passport, birth certificates etc can demand time away from office.

Companies have responded to the evolving set of issues related to work-life balance by introducing a wide variety of work-life balance practices. While practices vary across companies, most organizational initiatives include several major types of programs. Most notably, many companies introduce paid vacation, flexible work arrangements (flexi time or working from home), employee assistance program, concierge services, fitness centre, child care centre, paid or unpaid maternity and paternity leave etc.

The conversion rate of US Dollar against Indian Rupee has influenced a number of companies, especially in the Information Technology (IT) to optimise existing capacities and increase efficiency. All this could potentially force the employees to work harder at the expense of their personal lives to meet targets. The current state of the aspiring Indian society also contributes to the extra hours people spend for work as the hunger to acquire material comforts, wealth and "make hay while the sun shines" attitude of the young and middle class population seems to be on the rise. Another aspect that has not been focussed on this subject is the reason for extra hours spent by employees. While it is debatable that the extra hours spent by employees may or may not result in higher productivity, it certainly reduces the time spent with family and friends. Reasons for extra hours spent could be due 
Instrument Development For Studying Work Life Balance Programs in Information Technology Firms

to tight deadlines imposed by manager or senior management, poor utilization of resources by employee, poor coordination, incompetency, lack of training, poor work allocation, less planning, over-anxiety on the part of the employee. Employees at times, tend to get in "work" mode even at home by checking their emails, getting engaged in telephonic discussions or perform work from home on weekends thereby allowing family time to be reduced, even though there is no pressing need to do "work" on weekends.

According to the 1998 Far East Economic Review, in general, urban Asians worked an average of 2149 hours per annum vis-à-vis 2068 hours for South Americans, 1898 hours for North Americans and 1773 hours in Europe. It was also reported that the work life balance issues reported by employees had a direct co-relation with the hours spent. The intensity of work has increased. Intensification affects all countries in the world, all industry sectors and all occupational categories. Changes in technology (IT and telephony) give employers more flexibility in terms of the way they ask people to work. $80 \%$ of managers said that virtual working (also called e-working) is a key business issue, according to a 2003 Roffey Park report.

According to Society of Human Resource Management (SHRM), US, in a 2001 survey conducted by the Radcliff Public Policy Centre, $82 \%$ of men and $85 \%$ of women aged 20 to 39 placed family time at the top of their work/life priorities.

SHRM also highlights that in a 2001 study by Rutgers University and the University of Connecticut, 90\% of working adults said they are concerned they do not spend enough time with their families.

Research by Parasuraman and Greenhaus (2002) documented that segments of the workforce may be subject to unique work/family pressures, yet often have few sources of support. 4 The under-representation of these groups of individuals with potentially difficult types of work/family pressures represents a major gap in work/family research and employers' understanding of their needs. Typically, studies have focused on employed men and women who are married or living with a partner or those with children. Omitted from research are single-earner mothers and fathers, single and childless employees with extensive responsibility for eldercare.

In their highly acclaimed book, Work and Family_-Allies or Enemies, Friedman and Greenhaus (2000), two leaders in work/life balance, bring forth new evidence to help us understand choices we make as employers and individuals regarding work and family. This pioneering study of more than 800 business professionals considered values, work, and family lives and found that "work and family, the dominant life roles for most employed women and men in contemporary society, can either help or hurt each other." To handle work/life balance, Friedman and Greenhaus emphasize that working adults learn to build networks of support at home, at work, and in the community. Conflict between work and family has real consequences and significantly affects quality of family life and career attainment of both men and women.

A work/life balance survey conducted in 2002 by True Careers states that $70 \%$ of more than 1,500 respondents said they don't have a healthy balance between their personal and work lives.

"Holding a Job, Having a Life: Strategies for Change" 2001 study by the Work Institute of America points out that employee-driven solutions help reduce overtime, stress, and workloads, and increase flexibility and family and leisure time.

A study (1997) was conducted by WFD (formerly Work/Family Directions) with research focused on work/life programs with a number of clients (e.g., DuPont, Johnson \& Johnson, Hoechst Celanese, IBM, and others). At DuPont, for example, "employees who used the company's work/life programs were $45 \%$ more likely to agree strongly that they will 'go the extra mile' and are least likely to feel overwhelmed or burned out". Data from Hoechst Celanese documented that "some $60 \%$ of those surveyed reported the ability to balance work with personal and family responsibilities was of great importance in their decision to remain with the company.

The key findings from the Work Life Balance Employer Survey conducted by the National Centre for Social Research, UK in 2000 are, more than nine in ten employers (94 per cent) were of the view that people work best when they can strike a better balance between work and the rest of their lives, the majority of employers agreed that trying to accommodate employees with their different patterns of work was not easy (65 per cent) and around two-fifths (42 per cent) of employers considered that work-life balance policies were unfair on some employees.

Thus when a study to determine the state of work life balance in India in Information Technology industry was thought about, a need for developing an instrument to measure work life balance in Indian Information Technology was felt. This paper deals with the construct of the instrument for this particular industry in an Indian context taking into consideration the variables involved. Earlier studies made in this subject are not relevant to the Indian context and for the current generation.

\section{Need For An Instrument}


Instrument Development For Studying Work Life Balance Programs in Information Technology Firms

The attempt is to study the work life balance practices, types of programs available in Indian Information Technology landscape and also to determine the level of awareness on work life balance programs at junior and middle level employees. The research also deals with identifying whether there are any challenges in meeting work and family commitments. Further the research is to investigate whether the work life imbalance is employer-driven or employee-driven and to spot the top 3 risks for employers in India in encouraging employees to work from home. There has been no comprehensive research of this nature in India previously. Applying instruments created earlier in other country may not yield the desired results due to several reasons including cultural sensitivity of Indians, the nature of work being performed in India, outsourced service provider environment that is prevailing, young Indian workforce in the industry, current state of Indian economy, tendency to spend more money by the Indian work force these days, growing number of nuclear families, the need to stay independent and awareness and implementation of labour laws in India. Hence a need for a new instrument specific to Indian Information Technology industry is felt to facilitate the research keeping the above-mentioned unique set of variables in mind. More importantly, an instrument that facilitates in capturing the data and to meet the specific objectives of the study was required. This necessitated the development of a new instrument for the specific purpose.

\section{Instrumentation}

For the purpose of studying the objectives and testing the hypotheses, a questionnaire was used as an instrument to collect the data. The questionnaire has four parts with respect to Independent Variables: the first part measures the Breadwinner - Single/Dual income, demography and basic needs. The second part measures the Quality of work life experienced including career orientation and knowledge. The third part deals with Power of Money and Consumerism and its influence of workforce. Finally, the fourth part deals with other interests including hobbies, society and friends.

Thus the variables chosen for this study are the four items mentioned above. Purpose is to capture and understand the impact these individual drivers have on work life balance or absence of it, if any. It captures the basic demographics, tenure with current employer, total work experience, family role, family versus work priorities, intervention made by employers, reasons for imbalance, stages where imbalance may occur, role of technology gadgets, supervisor support and so on. Care has been taken to measure the influence of moderating variables like availability of program/policy/process at work place offered by employer and extent to which they are utilized by employees. The items capturing each factor were adopted from standardized questionnaires developed or used by earlier researchers. However, they were subjected to validity and reliability tests. Hence, the items that constituted adequate coverage of the factors under study were decided and agreed upon by the researcher.

Accordingly, the first part consisting of the information related to Breadwinner, single/double income including age captures as a direct measure, sex, total work experience, tenure with current employer, marital status, no of children, spouse employment and nature of job are captured. Age is categorized as $20-30$ years, more than 30 and up to 35 years, more than 35 and up to 45 years and more than 45 years. Similarly total work experience was categorized as up to 3 years, more than 3 years and up to 7 years, more than 7 years and up to 15 years, more than 15 years and up to 25 years and more than 25 years. Tenure with current employer is categorized as up to one year, more than one year and up to three years, more than three years and up to six years, more than six years and up to eight years and more than eight years. To identify working pattern, if any in the different nature of jobs in Information Technology industry, the jobs are classified as Application Development/Support, Business Analysis, Information Technology Infrastructure, Enablers Group that includes Quality, Finance, Human Resources, Facilities, Administration, Sales Support and Marketing and Others.

The second part of the instrument consists of Quality of work life. It captures different IT skills, current job position and average time spent on work per week normally during a work week, which is Monday through Friday. Choices are less than 35 hours, $35-40$ hours, $40-50$ hours, $50-60$ hours and more than 60 hours. The instrument also captures the number of times the respondents have worked on weekends/holidays in the last one year. The intent here is to find out hours spent on work and to check if a conflict exists between work and family. To get more insights on the conflict, if any instrument also captures the respondents view on work schedule and the extent to which he/she is comfortable with it. Time spent on commuting to and fro to work is also captured as it has a bearing on the balance that needs to be maintained. 5-point Likert scale is used extensively in the instrument. For example, to check how career oriented the respondent is, options given are Strong Disagree, Disagree, Undecided, Agree and Strongly Agree. Some of the other aspects related to quality of work life includes, effort put in to seek extra knowledge to prepare for future, work atmosphere, support from supervisor, opportunities at work to learn and grow, attitude towards career growth, recognition at work, life's priority and extent to which respondent is preoccupied with work at home, wherever applicable. 
Instrument Development For Studying Work Life Balance Programs in Information Technology Firms

The third part of the instrument consists of Power of Money and Consumerism. It captures the income earned, desire to acquire material comforts, gadgets, house, and attitude towards hire purchase/loans. The fourth part of the instrument deals with other interests and hobbies.

Now the moderating variables are introduced in the instrument in the form of questions related to benefits offered by employer, explanation of benefits offered and respondents' interest in learning the benefits and extent to which they were utilized for personal benefit. The definition of Work Life Balance as per the respondent is also captured directly to avoid ambiguity. More questions follow that affects work life balance, the role of modern gadgets in work life balance to check whether they are a boon or bane. The instrument also deals with peer pressure when it comes to spending extra hours at work. The respondents' perception on maintaining work life balance is also asked. Questions related to external help from psychologist/mentor/specialist, work versus family conflict, commitment towards work and family are also posed. This part of the instrument deals with family role characteristics. Family demand scale consisted of four items adopted from Yang, Chen, Choi, \& Zou (2000); family conflict five items adopted from Higgins, \& Duxbury (1992); family support consisted of four items out of which three were taken from Joplin, Nelson, \& Quick, (1999) and one from Carlson \& Perrewe (1999) and family involvement was drawn from Lodahl \& Kejner's (1965) scale, quoted in Lobel, \& Clair, (1992) with the word 'job' replaced with the word 'family'.

Similarly it consists of the items covering the work role characteristics as well. Work demand scale consisted of four items adopted from Williams, \& Alliger (1994); Work conflict twelve items adopted from Higgins, \& Duxbury (1992), Supervisor support consisted of six items originally developed by Shinn, Wong, Simko, \& OrtizTorres, (1989) and adopted from Batt, \& Valcour (2003) and Job involvement consisted of a shortened form of Lodahl \& Kejner's (1965) scale, quoted in Lobel, \& Clair, (1992). The instrument also deals with work family conflict with questions related to vacation taken, challenges faced in giving $100 \%$ to family and $100 \%$ to work, hurdles in facing work and family commitments. Work family conflict (WFC) scale consisted of 9 items out of which 5 items were quoted in Carlson \& Perrewe (1999), one was taken from Carlson, Kacmar, \& Williams (2000), one from Mallard, \& Lance (1998), two from Carlson, Kacmar, \& Williams (1998). Similarly, family work conflict scale consisted of 9 items out of which 5 items were quoted in Carlson \& Perrewe (1999), one was adopted from Carlson et al., (2000), one from Mallard, \& Lance (1998) where the word 'job' was replaced with 'family' and 'parent' was replaced with the term 'employee', and two from Carlson et al (1998).

The final part of the instrument deals with threats to work life balance, factors that contributes to work life imbalance, if any, working from home related issues including perspective as an employer and as an employee, factors that impact working from home and employer's concerns related to working from home and employee's concern as well.

\section{Validity Test}

The questionnaire was subjected to face and content validity whose determination was judgemental. There are two schools of thought on the distinctiveness of face and content validity. The first one saw face validity as just an indirect approach to the measurement of content validity (Carmines, \& Zeller, 1979; Nunnally, 1967) whereas the second one treated them as separate and different tests (DeVellis, 1991; Kerlinger, 1973). In this study, the researcher has subscribed to the second perspective where quantitative assessment of the content validity has been followed.

The face and content validity was conducted in two stages. In the first stage, it was conducted with 4 experts and in the second with 8 experts. The experts scrutinised the items, according to the definition generated against the constructs of Breadwinner, Quality of Work Life, Power of Money and Consumerism and Other Interests/hobbies, Availability of work life balance programs, policies, processes and offered by Employer, Utilization of work life balance programs by Employee, Work Life Balance factors, work family conflict, Challenges in meeting family and work commitments, Peer pressure and Working from home related issues. The set of experts in the first stage were not able to give a conclusive opinion on the inclusion of behaviour-based Work life balance items in the scale, though they agreed on the other items of the scale. They were inconsistently divided throughout the validity test process. Nevertheless, the researcher conducted the pilot study without the behaviourbased W-F conflict items. Later, the experts themselves consensually suggested that few more experts need to be included. They also suggested the researcher to discard the results of the first validity tests. Based on their suggestion, four more experts were included. Before they offered their opinion on the items, the researcher informed them of the objectives and the need for the study. The experts were first encouraged to discuss among themselves, the validity of each item in capturing the adequate information required for the study. Then they were requested to offer their feedback on each of the items. Based on their feedback, few items were slightly modified, 
Instrument Development For Studying Work Life Balance Programs in Information Technology Firms

reworded, repositioned to make them appropriate for use. For example, the family demand item "How much has time spent with family come down?" was reworded as "Time spent by me for family has come down". The experts also suggested a 5-point rating scale for all the items. The Content Validity Ratio (CVR) was applied to each item, using the formula developed by Lawsche (1975). They are presented in table below. Based on this, a few redundant statements were removed.

Content Validity Ratio $=(\mathrm{Ne}-\mathrm{N} / 2) /(\mathrm{N} / 2)$

where $\mathrm{Ne}=$ number of panelists indicating "essential" and $\mathrm{N}=$ total number of panelists

With reference to Table 1 , all those items which have scored less than 0.50 on the content validity ratio have been removed from the study. Based on the face validity and content validity ratio, the final number of items in each of the factors taking part in this study was decided. Accordingly, the number of items included in each of the factors is as follows:

Breadwinner

Quality of Work Life

Power of Money and Consumerism

Other Interests/Hobbies

Work Life Balance Programs from Employer

Utilization of Work Life Balance Programs by Employee

Work Life Balance/Work Family Conflict

- $\quad 10$ items

- $\quad 21$ items

- $\quad 4$ items

- $\quad 3$ items

- $\quad 4$ items

- $\quad 5$ items

- $\quad 17$ items

As mentioned earlier, these items were made on a 5 -point scale anchored by $1=$ strongly agree; $2=$ agree; $3=$ undecided; $4=$ disagree and $5=$ strongly disagree and the mean of the items under each factor was used as a composite measure of the respective factors.

\section{The Pilot Study}

After finalising the number of items in the research instrument using face and content validity tests, a pilot study was undertaken for the following reasons:

a) To assess the reliability of the research instrument constructed.

b) To ascertain the time taken to complete the questionnaire by the respondents.

To conduct the pilot study, it was decided to select a company which employed over 500 employees in one location. From the chosen firm, 35 employees with at least 3 years of work experience including those who are married were drawn from the list of the sampling frame.

\section{Results Of The Pilot Study}

The verbatim record of the transaction that took place while administering the questionnaire was noted. The discussion with the employees during the pilot study revealed that the instrument has adequate stimulus value to gather authentic responses from the respondents. The transaction also suggested that the procedures adopted in administering the instruments are practicable. Hence it was concluded that the instrument used in the study would elicit the necessary data required from the respondents. It has been found that the respondents took invariably between $20-25$ minutes to completely fill the questionnaire.

\section{Reliability Test}

The data collected from the pilot study was subjected to reliability test using Cronbach Alpha (Table 2). The alpha values for the various dimensions are shown in Table 2. From the table, it has been found that the reliability coefficients for the variables chosen for this study are more than 0.60 , which is an acceptable value (Malhotra, 2004). So, the items constituting each variable under study have reasonable internal consistency.

Thus this instrument was found to be fit enough to administer to proceed with the research.

\section{References}

[1]. Claire McCartney (2003). Work-Life Balance: A Guide for organization, Roffey Park Institute (Online), http://newsite.roffeygroups.co.uk/wp-content/uploads2/Work-life-balance-the-role-of-the-manager.pdf

[2]. Adams, G. A. King, L. A. \& King, D. W. (1996). Relationship of job and family involvement, family social support, and work-family conflict with job and life satisfaction, Journal of Applied Psychology. 81, 411- 430.

[3]. Arthur, M.M. (2003). Share price reactions to work-family initiatives: An institutional perspective, Academy of Management Journal. 46(4), 497-505.

[4]. $\quad$ Aryee, S. Srinivas, E.S. \& Tan, H.H. (2005). Rhythms of Life: Antecedents and Outcomes of Work-Family Balance in Employed Parents, Journal of Applied Psychology, 90(1), 132-146. 
Instrument Development For Studying Work Life Balance Programs in Information Technology Firms

[5]. Ashforth, B.E.; Kreiner, G.E. \& Fugate, M. (2000). All in a day's work: Boundaries and micro role transitions, Academy of Management Review. 25, 472- 491.

[6]. Baltes, B.B. \& Heydens, H.A. (2003). Reduction of Work--Family Conflict Through the use of Selection, Optimization, and compensation Behaviors, Journal of Applied Psychology. 88 (6), 1005-1018.

[7]. Blau, G. (1995). Influence of group lateness on individual lateness: A cross-level examination. Academy of Management Journal. 38(5), $1483-1496$.

[8]. Brett, J.M. \& Stroh, L.K. (2003). Working 61 Plus Hours a Week: Why Do Managers Do It? Journal of Applied Psychology. 88(1), 67-78.

[9]. Caligiuri, P. M.; Hyland, M. A. M.; Joshi, A. \& Bross, A. S. (1998). Testing a theoretical model for examining the relationship between family adjustment and expatriates' work adjustment. Journal of Applied Psychology, 83, 598 - 614.

[10]. Edwards, J. R., \& Rothbard, N. P. (2000). Mechanisms linking work and family: Clarifying the relationship between work and family constructs. Academy of Management Review, 25, 178 -199.

[11]. Frone, M. R. (2000). Work-family conflict and employee psychiatric disorders: The national comorbidity survey. Journal of Applied Psychology, 85, $888-895$.

[12]. Frone, M. R., Russell, M., \& Cooper, M. L. (1992). Antecedents and outcomes of work-family conflict: Testing a model of the workfamily interface. Journal of Applied Psychology, 77, 65 -78.

[13]. Goff, S. J., Mount, M. K., \& Jamison, R. L. (1990). Employer supported child care, work/family conflict, and absenteeism: A field study. Personnel Psychology, 43,793 -809.

[14]. Nancy R. Lockwood, 2003 Quarterly Report, Society of Human Resource Management Research, Society of Human Resource Management

[15]. Kanter, R. M. (1977). Work and family in the United States: A critical review and agenda for research and policy. New York: Russell Sage Foundation.

[16]. Lambert, S. J. (2000). Added benefits: The link between work-life benefits and organizational citizenship. Academy of Management Journal, 43, 5, 801-815.

TABLE 1: CONTENT VALIDITY RATIO FOR THE ITEMS

\begin{tabular}{|c|c|c|c|}
\hline Variables & No. & Items & CVR \\
\hline Quality of Work Life & 1. & I seek to gain extra knowledge to prepare myself for future & 1.00 \\
\hline Quality of Work Life & 2. & I am career-oriented & 0.75 \\
\hline Quality of Work Life & 3. & At work, my opinion seems to count & 0.75 \\
\hline Quality of Work Life & 4. & $\begin{array}{l}\text { My supervisor or someone at work seems to care about me } \\
\text { as a person }\end{array}$ & 1.00 \\
\hline Quality of Work Life & 5. & $\begin{array}{l}\text { I am being reasonably recognized for my achievements at } \\
\text { work }\end{array}$ & 0.75 \\
\hline Quality of Work Life & 6. & $\begin{array}{l}\text { Time spent by me for family/friends/society has come } \\
\text { down }\end{array}$ & 0.75 \\
\hline Quality of Work Life & 7. & $\begin{array}{l}\text { On reaching home after work, I am pre-occupied with my } \\
\text { work activities }\end{array}$ & 0.75 \\
\hline Quality of Work Life & 8. & $\begin{array}{l}\text { During weekends when I am at home, I think about work or } \\
\text { work from home }\end{array}$ & 1.00 \\
\hline $\begin{array}{l}\text { Power of Money and } \\
\text { Consumerism }\end{array}$ & 9. & $\begin{array}{l}\text { I have a burning desire to acquire material comforts like } \\
\text { gadgets/amenities/car }\end{array}$ & 0.75 \\
\hline $\begin{array}{l}\text { Money and } \\
\text { Consumerism }\end{array}$ & 10. & $\begin{array}{l}\text { If I need any material comforts, I would not hesitate to go } \\
\text { for loans/hire purchase most of the time }\end{array}$ & 1.00 \\
\hline Other interests/hobbies & 11. & $\begin{array}{l}\text { I am able to spend sufficient time on my hobbies/special } \\
\text { interests }\end{array}$ & 1.00 \\
\hline Other interests/hobbies & 12. & $\begin{array}{l}\text { I picked up a new hobby/special interest in the last } 6 \\
\text { months }\end{array}$ & 1.00 \\
\hline $\begin{array}{lr}\text { Work Life } & \text { Balance } \\
\text { Programs } & \text { from } \\
\text { Employer } & \\
\end{array}$ & 13. & $\begin{array}{l}\text { My company has taken adequate steps to explain benefits to } \\
\text { me in some form or the other }\end{array}$ & 1.00 \\
\hline $\begin{array}{lr}\text { Work Life } & \text { Balance } \\
\text { Programs } & \text { from } \\
\text { Employer } & \\
\end{array}$ & 14. & $\begin{array}{l}\text { I took personal interest in understanding benefits offered to } \\
\text { me by my company }\end{array}$ & 0.75 \\
\hline Work Family Conflict & 15. & I tend to ignore some of my family commitments & 1.00 \\
\hline Work Family Conflict & 16. & I need external help from a psychologist/mentor/specialist & 1.00 \\
\hline Work Family Conflict & 17. & My family commitments are high & 0.75 \\
\hline Work Family Conflict & 18. & I face challenges in giving $100 \%$ to my job & 1.00 \\
\hline
\end{tabular}


Instrument Development For Studying Work Life Balance Programs in Information Technology Firms

TABLE 2: RELIABILITY COEFFICIENTS USING CRONBACH ALPHA

\begin{tabular}{|l|l|}
\hline Variables & Reliability (Cronbach Alpha) \\
\hline Quality of Work Life & .826 \\
\hline Power of money and consumerism & .628 \\
\hline Other interests / hobbies & .886 \\
\hline Work Life Balance Program intervention & .853 \\
\hline Work Life Balance & .626 \\
\hline
\end{tabular}

